\title{
Psychomotor development of preschoolers with speech pathologies by means of art therapy techniques
}

\section{Desenvolvimento psicomotor de pré-escolares com fonoaudiologia por meio de técnicas de arteterapia}

\section{Desarrollo psicomotor de preescolares con patologías del habla mediante técnicas de arteterapia}

\author{
Svetlana Arkhipova1 ${ }^{\text {iD }}$, Olga Lazutkina ${ }^{1}$ iD \\ ${ }^{1}$ Mordovian State Pedagogical University, Saransk, Russia. \\ Corresponding author: \\ S.V. Arkhipova \\ Email: arhipova.swetlana2011@yandex.ru \\ How to cite: Arkhipova, S. V., \& Lazutkina, O. R. (2022). Psychomotor development of preschoolers with speech \\ pathologies by means of art therapy techniques. Revista Tempos e Espaços em Educação, 14(33), e17214. \\ http://dx.doi.org/10.20952/revtee.v14i33.17214
}

\begin{abstract}
The article examines the concepts of "psychomotorics" and "psychomotor development" and gives their characterization in preschoolers with speech pathologies, as well as analyzes art therapy technologies as an instrument for psychomotor development of children in this group. The goal of the study is to develop the organizational and methodical aspects of the psychomotor development of preschool children with speech pathologies by means of art therapy technologies. The research is founded on the general scientific research methods of analysis, synthesis, comparison, and generalization, as well as a pedagogical experiment (ascertaining, formative, and control) and empirical data analysis. The data obtained in the study are processed in Excel by mathematical statistics methods. The data obtained in the course of the study give evidence of the positive dynamic of the psychomotor development of preschoolers with speech pathologies after the experimental work with the use of art therapy technologies. Research data confirms that specially organized work with the use of art therapy technologies allows increasing the level of psychomotor development in children with speech impairments. The developed materials can be used by teachers of preschool educational organizations to improve the level of psychomotor development of preschoolers with speech pathologies by means of art therapy techniques.
\end{abstract}

Keywords: Psychomotor development. Art therapy techniques. Preschoolers with speech pathology. 


\section{RESUMO}

O artigo examina os conceitos de "psicomotricidade" e "desenvolvimento psicomotor" e apresenta sua caracterização em pré-escolares com fonoaudiologia, bem como analisa as tecnologias de arteterapia como instrumento para o desenvolvimento psicomotor de crianças desse grupo. 0 objetivo do estudo é desenvolver os aspectos organizacionais e metódicos do desenvolvimento psicomotor de crianças pré-escolares com fonoaudiologia por meio das tecnologias da arte-terapia. Métodos: A pesquisa está fundamentada nos métodos gerais de pesquisa científica de análise, síntese, comparação e generalização, bem como em um experimento pedagógico (apuração, formação e controle) e análise de dados empíricos. Os dados obtidos no estudo são processados no Excel por métodos de estatística matemática. Os dados obtidos no decorrer do estudo evidenciam a dinâmica positiva do desenvolvimento psicomotor de pré-escolares com fonoaudiologia após o trabalho experimental com o uso de tecnologias de arteterapia. Os dados da pesquisa confirmam que o trabalho especialmente organizado com o uso de tecnologias de arteterapia permite aumentar o nível de desenvolvimento psicomotor em crianças com deficiência de fala. Os materiais desenvolvidos podem ser utilizados por professores de organizações de educação pré-escolar para melhorar o nível de desenvolvimento psicomotor de pré-escolares com fonoaudiologia por meio de técnicas de arteterapia.

Palavras-chave: Desenvolvimento psicomotor. Técnicas de arte-terapia. Crianças em idade préescolar com fonoaudiologia.

\section{RESUMEN}

El artículo examina los conceptos de "psicomotricidad" y "desarrollo psicomotor" y da su caracterización en preescolares con patologías del habla, además de analizar las tecnologías de la arteterapia como instrumento para el desarrollo psicomotor de los niños de este grupo. El objetivo del estudio es desarrollar los aspectos organizativos y metódicos del desarrollo psicomotor de niños en edad preescolar con patologías del habla mediante tecnologías de arteterapia. Métodos: La investigación se fundamenta en los métodos de investigación científica general de análisis, síntesis, comparación y generalización, así como en un experimento pedagógico (comprobante, formativo y de control) y análisis de datos empíricos. Los datos obtenidos en el estudio se procesan en Excel mediante métodos de estadística matemática. Los datos obtenidos en el transcurso del estudio evidencian la dinámica positiva del desarrollo psicomotor de preescolares con patologías del habla luego del trabajo experimental con el uso de tecnologías de arteterapia. Los datos de la investigación confirman que el trabajo especialmente organizado con el uso de tecnologías de arteterapia permite incrementar el nivel de desarrollo psicomotor en niños con impedimentos del habla. Los materiales desarrollados pueden ser utilizados por profesores de organizaciones educativas preescolares para mejorar el nivel de desarrollo psicomotor de niños en edad preescolar con patologías del habla mediante técnicas de arteterapia.

Palabras clave: Desarrollo psicomotor. Técnicas de arteterapia. Niños en edad preescolar con patología del habla.

\section{INTRODUCTION}

The speech and psychomotor development of preschool children are closely intertwined and interdependent. It is predominantly through movement and speech that a child discovers the world around them, interacts with it, expresses their attitude to it, and develops and improves themselves. The fundamental principle of the educational process organization is the unity of intellectual, speech, and psychomotor development. Correction of psychomotor skills leads to fairly rapid improvement in speech and thinking of children. If preschool children have a speech pathology that complicates communication, the development of their psychomotor skills is hindered. 
The totality of human motor abilities manifesting in various motor skills in different types of activities is defined as motorics, which covers both voluntary and involuntary movements. Under psychomotorics we understand only those motor acts that are performed under the control of consciousness, i.e., only voluntary movements.

I.M. Sechenov characterizes psychomotorics as the manifestation of the forms of mental behavior through the muscular movements responsible for the gnoseological and praxeological functions and regulating the work of all human sense organs.

The problem of psychomotor development becomes the most acute in preschool children with speech pathologies. Children with speech impairments are children who experience abnormal development of speech with their hearing and intelligence being normal. Speech pathologies may manifest themselves in defects in pronunciation, the grammatical structure of speech, poor vocabulary, and impaired tempo and fluency of speech.

This category of children is characterized by general motor clumsiness, poor coordination of complex movements, insufficient accuracy in self-care and labor operations, difficulties in performing physical exercises. The imperfection of fine hand (finger) motor skills is observed in selfcare activities, in the use of cutlery, school supplies, various tools, in manipulation with small objects, toys, and other activities requiring fine differentiated finger movements. Deficiencies of facial and articulation motor skills cause paucity and inexpressiveness of facial expressions, difficulties, and sometimes impossibility of mastering the pronunciation of sounds that are challenging to articulate.

This circumstance calls for organizing the correctional and pedagogical process in a way that would provide a positive impact on the psychomotor development of a preschooler. There emerges the need for new nonconventional methods for the psychomotor development of preschool children with speech pathologies, among which are art therapy technologies. The means of art therapy allow correcting higher mental functions, improving the qualitative characteristics of movements, and developing children's personal qualities.

The productive implementation of such activity is impossible without proper organizational and methodical support. However, specialized literature gives little scientific and methodical recommendations on the problem of using art therapy exercises to develop the psychomotor skills of children with speech impairments.

The relevance of the outlined problem allows defining the purpose of the study as the development of the organizational and methodical aspects of the psychomotor development of preschool children with speech pathologies by means of art therapy technologies.

The theoretical materials provided in the study will supplement the data on the stated problem available in the scientific literature. The practical significance of the study lies in the fact that the developed organizational and methodical aspects of the use of art therapy techniques in the psychomotor development of preschool children with speech pathologies can be useful to specialists and teachers of preschool educational organizations in their professional activities.

\section{LITERATURE REVIEW}

Within the framework of the present study, it is critical to define the essence of the concepts of "psychomotorics", "psychomotor development", and "art therapy technologies".

The problem of psychomotorics has been examined from various positions.

According to physiologists (Pavlov, 2019; Sechenov, 2019), psychomotorics presents the final link in mental activity due to the close connection between mental processes and movement.

The neuropsychologist M.V. Bekhterev (1991) recognizes all motor manifestations, from elementary motor processes of the simplest cellular organisms in the form of the contractility of their protoplasm to various manifestations of human movements, as a result of the most complex processes of neuropsychological activity. 
Representatives of psychology, Russian researchers N.I. Gurevich and M.O. Ozeretskii (1930), suggest considering psychomotor skills through the prism of the relationship of conscious, automatic, and automated components of movement manifesting itself in precise, rapid, and consistent "adaptation" to the studied movement.

K.K. Platonov (1986) believes that psychomotorics is the main type of objectification of the psyche in the sensorimotor, ideomotor, and emotional-motor (in particular, impulsive) reactions and acts.

According to V.V. Nikandrov (2004), psychomotorics is a type of psychologically caused movements of a person, which typologically differ depending on the structure of their body, age, sex, etc.

Having reviewed various views on the essence of the concept of "psychomotorics", we can conclude that psychomotor development refers not only to a holistic age-related image of motor structure reflecting the inherent characteristics of one's body and the acquired habits and skills but also the totality of anatomic and physiological and psychological mechanisms providing for simple and complex motor reactions and acts (Sechenov, 2019).

The normal psychomotor development of preschool children is characterized by developed or developing motor skills and abilities, physiological properties (dexterity, swiftness of reaction, endurance), sufficiently accurate coordination of movements, spatial orientation, and balance. In this period, children already have cross-hand and leg coordination, and their spatial and short-term orientations improve.

The psychomotor development of preschool children diagnosed with speech pathologies differs in many ways from that of their normally developing peers. The category of children with speech impairments is extremely diverse. It includes children with psychophysical disorders of varying severity that cause impairments of communicative and generalizing (cognitive) speech functions. They are distinguished from other categories of children with special needs by normal physiological hearing, vision, and full prerequisites for intellectual development (Lopatina, 2003).

The psychological and pedagogical classification identifies disorders of linguistic means of communication (phonetic underdevelopment of speech, phonetic-phonemic underdevelopment of speech, general underdevelopment of speech) and disorders in the use of means of communication in the process of speech communication (stuttering).

According to the clinical and pedagogical classification, speech disorders are divided into disorders of oral speech (dysphonia, bradyllia, tachylalia, stuttering, dyslalia, dysarthria, alalia, aphasia) and disorders of written speech (dyslexia, dysgraphia, dysfography) (Volkova \& Shakhovskaia, 1998).

In general, children with speech pathologies are characterized by poor coordination and switching of movements, lack of spatial perceptions and a sense of rhythm, insufficient development of motor functions, and weakness of mental processes (Morozova \& Garusova, 2016).

In his research, V.P. Dudev characterizes the features of psychomotor development in preschool children with speech disorders. For example, in children with dyslalia, he notes insufficiency of articulatory motor skills, imperfect motor-kinesthetic analyzer, difficulties in mastering the necessary coordination of verbal movements, insufficiency of manual motor skills, and imperfect fine involuntary movements of hands and fingers (Dudev, 2020).

In preschool children with rhinolalia, the movements of the muscles of the speech apparatus from an early age are characterized by certain sluggishness, lethargy, clumsiness, which characterizes their articulation. In facial motor skills, there is amissiveness, limited and unexpressive facial movements, phenomena of synkinesia in facial muscles. Physical underdevelopment of children with congenital cleft palate causes insufficiency of general and hand voluntary motor skills manifested in violations of coordination, fluidity of movements; lack of a sense of rhythm and tempo, which is reflected in the nature of many movements. The muscles of the fingers and hands 
are weak and quickly tired, as a result of which their movements are not coordinated (Davydova, 2008; Dudev, 2020; Sirotiuk, 2009).

In preschool children with dysarthria, the movements of the mimic and articulation muscles are characterized by rapid exhaustion, low quality, and lack of precision, fluidity, and range. Most of the articulation movements are available to them, but their quality suffers. The movements are blurred and indistinct, there is weak muscle tension, arrhythmicity, limitation of the amplitude of movements, rapid muscle fatigue. The general motor features are characterized by the limited range of movements, their awkwardness, and slowness. Deficiencies in fine motor skills are expressed in the impaired accuracy, speed, simultaneity, and coordination of movements (Dudev, 2020).

Psychomotor deficiency in preschool children with alalia encompasses all components of the motor sphere: general motor skills, fine hand and finger movements, and articulatory and mimic motor skills, i.e. the motor system as a whole. These children demonstrate clumsiness, discoordination of movements, slowness or disinhibition, fine motor coordination of the speech apparatus is not formed, fine motor skills of the hands are difficult (children cannot tie shoelaces, fasten or unfasten buttons and locks) (Dudev, 2020).

Stuttering preschool children have defects in general, verbal, articulatory, and mimic motor skills. Speech motorics disorders manifest themselves as violent movements - tics, speech spasms. These children show motor clumsiness, lack of mobility, stiffness, slowness of all movements, sometimes with limitations of their range (Dudev, 2020).

The indicated features of the psychomotor development of preschool children with speech pathologies necessitate a search for new, non-traditional means of correction, among which are art therapy technologies.

At present, the concept of "art therapy" (therapy by means of art) is viewed both as the totality of the types of art used in treatment and correction, as the set of art therapy methods, and as a direction of psychotherapy and psychocorrection practice. In recent years, art therapy has been increasingly incorporated in the correction and development process in educational organizations for children with various variants of developmental disorders and yields positive results (Susanina, 2007).

Education for persons with disabilities employs the following types of art therapy: visual arts therapy, music therapy, kinesitherapy, bibliotherapy, cartoon therapy, imaginative therapy.

One of the effective instruments in corrective and pedagogical work, the use of which provides a natural opportunity for the development of a child's hand-eye coordination, is visual arts therapy - correction by means of the visual forms of creativity. Although it typically involves painting, the means of visual arts therapy can include the use of plasticine, clay molding techniques, decorating classes, and photography. Visual arts therapy not only performs a psychotherapeutic function but also promotes the development of volitional fine hand and finger movements of children and activates their cognitive processes.

Music therapy is a type of art therapy that uses music for therapeutic and correctional purposes (Susanina, 2007). Music gives special expressiveness to children's movements in play and dance, influences children's feelings, deepens their understanding of various phenomena of nature, promotes the formation of a proper attitude toward the surrounding world. Music-making, which is based on musical and rhythmic movements, is an excellent means of developing both the musical and rhythmic abilities of children and their psychomotor characteristics. Both passive music therapy and active music therapy are used in treatment. Active music therapy can take the form of vocal therapy, dance therapy, choreotherapy, remedial rhythmics, and psychogymnastics.

The types of music and movement therapy based on the unity of music and movement, on the active motor activity of the child to the sound of music, have in recent years been increasingly considered as components of a single independent direction - kinesotherapy. Kinesotherapy 
(kinesiotherapy, kinesitherapy) refers to treatment with active and passive movements. Complexes of kinesiotherapeutic exercises aimed at the development of gross motor skills improve the coordination of movements, orientation in space and one's own body, more confidence is shown in walking, jumping, and running. The ability to react immediately and dexterity in ball games is developed. Exercises specifically targeted at the development of fine motor skills contribute to mastering the ability to skillfully use scissors, freely draw with a pencil and paints. Systematic use of kinesiotherapeutic body, oculomotor, and breathing exercises promotes the development of interhemispheric interaction, which has a stimulating effect on the working capacity of the brain and the development of the cognitive component of psychomotor functions. This technology allows minimizing anxiety and emotional stress, normalizing the processes of self-regulation and selfcontrol, which influence the organization of one's activity and behavior, thus promoting successful social communication (Arkhipova \& Podshivalova, 2021b).

Bibliotherapy is a method of art therapy that utilizes reading and literature in optimizing the mental, physiological, and biological processes in the body. A distinction is made between controlled and spontaneous bibliotherapy. Controlled bibliotherapy is understood as a purposeful activity of the teacher who uses books for corrective influence on the child. Spontaneous bibliotherapy is a spontaneous effect of a book on the personality of the reader. In this case, much depends on the artistic soundness of the book, the alignment of its subject matter with the problem that worries the child reader (Susanina, 2007).

Cartoon therapy is one of the directions of art therapy, therapy with film art. There are two directions in cartoon therapy: the active, which involves the creation of cartoons, and passive viewing the existing cartoons. The essence of the first direction of cartoon therapy lies in the creation of a cartoon with the direct participation of a child. A child can be a screenwriter, director, costumier, actor, or master of dubbing. In the process of preparing an animated film, children develop spatial perceptions, coordination, and switchability of hand movements; the process of perception of the lexical material is activated; lexical and grammatical means of language are developed; coherent speech and communicative competence are formed. In the second direction, children develop the ability to self-expression and self-knowledge, the correction of their behavior. In the process of watching cartoons, children develop the ability to recognize feelings and emotions, overcome their fears, and counter difficulties.

Imaginative therapy presupposes psychocorrective influence through image and theatricalization. It can take the form of puppet therapy, imaginative drama therapy, psychodrama, and theatrical activity.

Puppet therapy is used in work with children and is based on their identification with the image of a favorite character (in a fairy tale or a cartoon, a toy). This technology is used for various behavioral disorders, fear, difficulties in the development of the communicative sphere, etc.

Imaginative drama therapy involves dramatization as a technical method - playing out a certain plot. The power and depth of influence of drama therapy are due to the opportunity to express events and experiences vividly, clearly, and precisely, which makes it possible to remember and experience certain life events differently, to take a different look at them.

Psychodrama is a technique of group work that involves a role-playing game in which dramatic improvisation is used as a way of exploring the inner world of children and creating conditions for the spontaneous expression of feelings.

Theatrical activity is a creative activity associated with modeling images and relationships using various expressive means: mimics, gestures, pantomimics. The development of psychomotor skills occurs through playing various nursery rhymes, fairy tales, poems, thereby developing general coordination, hand movements, and dexterity. Currently, there are the following types of theatrical activities: finger puppet theater, toy theater, puppet theater, tabletop theater, flannelgraph theater, matryoshka-tales, masks theater, cardboard theater. 
Having analyzed art therapy technologies, we can conclude on the high efficiency and variability of their use in correctional work with preschool children with speech pathologies. In our study, we consider it expedient to resort to one of the forms of imaginative therapy - finger puppet theater.

\section{METHODS}

The study is based on the use of theoretical methods (analysis of psychological and pedagogical research on the problem under study), empirical methods (psychological and pedagogical experiment; modeling corrective and pedagogical work on the psychomotor development of preschool children with speech pathologies using art therapy technologies), and data processing methods (quantitative and qualitative analysis).

The first stage of the study involves theoretical analysis of psychological and pedagogical and methodical literature conducted to identify the essence of the concepts of "psychomotor development" and "art therapy technologies" and determine the specific characteristics of psychomotor development in the studied category of preschool children. The second stage involves the study of psychomotor development in preschoolers with speech pathologies. The third stage consists in the development of the content and implementation of experimental work on the psychomotor development of the identified category of children by means of art therapy techniques, the analysis and interpretation of the results of the study, and testing its effectiveness.

The experimental study is conducted based on the Municipal Preschool Educational Institution (MPEI) "Kindergarten No. 36 of the combined type", MPEI "Kindergarten No. 82 of the combined type", and MPEI "Kindergarten No. 97 of the combined type" in the city of Saransk (Russia). The study sample consists of 30 preschool children aged 5-6 years old with logopedic diagnoses of "General underdevelopment of speech. 1st level of speech development", "General underdevelopment of speech. 2nd level of speech development", and "General underdevelopment of speech. 3rd level of speech development".

The study of the level of psychomotor development of preschool children with speech impairments is carried out taking into account the motivational, orientational-operational, and regulatory components of psychomotor activity.

The motivational component covers the features of the preschoolers' emotional attitude to psychomotor activity, interest in the offered tasks, and the presence of aspiration to continue work.

The study of the orientational-operational component is based on the works of L.A. Golovei, N.I. Gurevich, N.O. Ozeretskii, and E.F. Rybalko and involves assessing the indicators of psychomotor development (Bezborodova, 2019).

The regulatory component of psychomotor development assumes the presence of selfregulation of psychomotor activity in preschool children with speech disorders, completeness of acceptance of a task condition and its maintenance until the end of the performance, the quality of self-control during the performance of tasks and the evaluation of its results.

The motivational and regulatory components of psychomotor activity are assessed through direct observation of the diagnosed individuals in the process of them performing experimental tasks. The study of the orientational-operational component involves a selection of methods in five areas:

- assessment of static coordination - the methods "Assessment of the ability to differentiate muscle tension" (L. A. Golovei, E. F. Rybalko), "Static equilibrium” (N.I. Ozeretskii, M.O. Gurevich);

- assessment of dynamic coordination - the methods "Dynamic coordination" (N.I. Ozeretskii, M.O. Gurevich), "Reproduction of rhythm" (L.A. Golovei, E.F. Rybalko), "Graphic tests" (M.O. Gurevich);

- assessment of the speed of movement - the methods "Speed of movement" and "Simultaneous movement" (N.I. Ozeretskii, M.O. Gurevich); 
- assessment of the power of movement - the methods "Power of movement" (strength of the squeeze of the right and left hands) and "Distinctness of movement performance" (N.I. Ozeretskii, M.O. Gurevich);

- testing for synkinesias - the method "Accompanying movements" (N.I. Ozeretskii) (Bezborodova, 2019).

The conducted experimental learning involves testing one of the methods of imaginative therapy - finger puppet theatre. Finger puppet theatre is a set of character figurines that are put on each finger. These can be individual puppets, animals, some objects for the staging of a fairy tale or all the familiar characters of favorite Russian folk tales.

The technology of experimental work on the use of finger puppet theater as a means of psychomotor development of children with speech pathologies consists in the selection and adaptation of its repertoire. In accordance with L. Lopatina's program "Approximate Adapted Educational Program for Preschool Children with Severe Speech Disorders" (Pavlov, 2019), the repertoire of the finger puppet theater includes plays based on the following works: "Fear Has Big Eyes" (G. Grebner), "Porridge from the Axe" (Russian folk tale), "Rooster, the Golden Comb" (Russian folk tale), and "Little Red Riding Hood" (C. Perrault).

The repertoire of the finger puppet theatre is tested in the process of club work of a theatre studio "Young Artists", the main objective of which is the improvement of the psychomotor development of preschool children with speech pathologies through art therapy technologies. The club lessons are held twice a week in the afternoon. The corrective and pedagogical work includes a total of 12 club lessons of 30 minutes each.

Corrective and pedagogical work on the psychomotor development of children with speech pathologies in the theater studio is carried out in stages.

The first preparatory stage involves forming preschoolers' motivation to not only take part in the work of the puppet theatre but also work on the improvement of their psychomotor development indicators (static and dynamic coordination, speed and power of movement), which are important for the high-quality organization of a finger puppet theatre performance. During the familiarization with the types of puppet theatre and while watching finger puppet performances, children's attention is focused on the dexterity of the movements of artists controlling the puppets with a discussion of the errors arising from inaccurate hand and finger movements.

The second stage focuses on preschoolers' familiarization with works of fiction and actively involving them in the process of selecting the finger theater repertoire, as well as in the conscious distribution of roles. Conversations with children involve analyzing the work, its characters, their appearance, emotions, and character of behavior. In addition, motor games and finger exercises performed in pairs or groups are used at this stage, allowing to establish contact and organize cooperation between the participants of the theater studio, as well as to improve their psychomotor skills.

The third stage involves the design of characters, the work on creating the image of the characters and their embodiment in finger puppets. Together with parents and teachers, preschoolers design the appearance of the future characters of the performance from fabric, colored paper, natural materials, and solid household waste. In this, adults are given only the supervisory role, while the production of the finger character remains the child's prerogative. Before the start of this work, the children perform a special set of exercises to warm up the fine motor skills of fingers and prepare them for fine and precise movements. In the process of making the characters, the preschool children, repeating the movements of adults, activate manual motor skills, develop dexterity, the ability to control their movements, and focus their attention on individual motor acts. To avoid muscle overstrain, the work is interrupted by small dynamic pauses and relaxation exercises. 
The fourth stage focuses on the children memorizing the lines of their characters. Through numerous repetitions of the phrases in game situations and by showing the character in different actions, preschool children memorize the necessary speech material. Our study deploys motor-roleplaying games in which the children with finger puppets take turns acting as a leader, giving minitasks, or evaluating the work of their companions.

The fifth stage involves the rehearsal of the theatre performance. The preschoolers voice the lines of their characters, practice their intonation and movements. At this stage, particular attention is focused on the correctness and emotionality of children's speech, teaching them the correct sequence of presenting the lines in accordance with the plot of the play. One of the main directions of correctional and pedagogical activity is work on the accuracy of each child's movements: improving static coordination, which is necessary when holding a certain pose for a long time during the performance; developing dynamic coordination and proportionality of movements when building a spatial composition of the location of the characters; forming the accuracy of fine motor skills, the speed of the change of movements, and the differentiation of their force in work with the finger puppet; improving the clarity of the child's movement.

The sixth stage consists in the final performance of the play to parents, teachers, and the kindergarten administration. The main focus in this is creating a favorable atmosphere in which the preschoolers would feel comfortable. The performance itself is presented to students as a game that the adults want to learn to play. In case of difficulties (forgetting lines, violation of spatial composition, etc.), the children are given support, a situation of success is created for them. The preschoolers pay special attention to their speech, monitor its clarity and intonational expressiveness, voice their lines in time, listening to each other closely without interrupting. The use of the finger puppets promotes the development of mobility and coordination of fingers on both hands, helps to learn the speech of characters, enrich the children's vocabulary, and activate their speech functions.

At the final evaluation and reflection stage, a discussion of the play is held. After watching it, each child is asked to identify their own mistakes, including those in terms of movement (wrong spatial positioning of the character, weak differentiation of movements, immobility of the finger puppet, or, on the contrary, too abrupt changes in its position, limited view of the character because of the incorrect positioning of hands behind the screen, etc.). At the same time, the other children, on the contrary, look for strengths in the performance of a companion and point them out.

The realization of these stages is accompanied by active interaction with teachers and parents of preschool children with speech pathologies, as only collaborative work of all subjects in the educational process ensures the creation of a uniform space for children's psychomotor development. With the teachers' support, the children's psychomotor indicators are improved through special finger games and motor exercises that children learn in the process of familiarizing themselves with the works of art, creating finger puppets, and playing the actions of the characters. Interaction with the parents makes it possible to consolidate the acquired skills at home.

The art therapy technology chosen for the present study allows for specially organized psychomotor development of preschool children with speech impairments accounting for all components of psychomotor activity. The first preparatory stage of corrective and pedagogical work is aimed at the realization of the motivational component. The orientation-operational component is revealed during the following five stages in preparation for the performance and its final demonstration. The regulatory component is most actively realized at the final evaluation and reflection stage. Thus, the use of art therapy, particularly finger puppet theater, provides a wide range of opportunities to improve the psychomotor development of preschool children with speech disorders. 


\section{RESULTS}

In this section, we review the results of the study of the level of psychomotor development of preschool children with speech pathologies before and after the experimental learning.

The assessment of static coordination indicates that at the ascertaining stage of the experiment, $36.7 \%$ of the examined children show the ability to stand with eyes closed alternately on the right and left leg and in the "stork" pose, whereas in the control experiment, this number reaches $63.3 \%$. The rest of the children do not hold the position, fall, stagger, or make jerks to the sides while performing the tests, resorting to visual control. Meanwhile, $33.3 \%$ of preschool children with speech pathologies are unable to differentiate muscle tension both before and after the experimental training.

Dynamic coordination of the upper extremities (when throwing the ball at the goal) and the lower extremities (when pushing forward a box of matches with the toe of one foot while jumping on the other foot) is developed in $30.0 \%$ of the examined students in the ascertaining experiment and $76.7 \%$ of children in the control experiment. Frequent mistakes in the reproduction of rhythm are made by $26.7 \%$ of preschool children with speech pathologies both before and after the experimental learning. In graphic tests ("Connect Dots", "Redraw Figures", "Fence"), gross violations in the smoothness of movement, inaccuracy of drawing with frequent interruptions and exits outside the field, and gross micro- and macrography are found in $70.0 \%$ of children at the ascertaining stage of the study, while at the control stage, this indicator decreases to $33.3 \%$.

The study of the speed of movement shows that before the experimental training, only $16.7 \%$ of the preschool children demonstrate the speed of movement when drawing lines with a pencil between the lines on a sheet in 1 minute. At the control experiment stage, this indicator reaches $33.3 \%$. Simultaneous movements (extending two arms in front of the chest, squeezing one arm and unclenching the other, etc.) are demonstrated by $50.0 \%$ of the examinees at the ascertaining stage and $76.7 \%$ of preschoolers at the control stage of the experiment. Rapid exhaustion of movement strength is diagnosed in $23.3 \%$ of the children both before and after the formative experiment.

In the assessment of the kinesthetic and kinetic basis of finger movements ("Make a Hare", "Make a Horned Goat", "Fist, Rib, Palm", "Rings"), slowed down completion of tasks with the help of the other hand (bending/extending fingers with the other hand, holding the desired posture when synkinesia occurs) is observed in $70.0 \%$ of the children before the experimental learning and only $33.3 \%$ of the preschoolers with speech pathologies during the control experiment.

At the ascertaining and control stages of the experiment, based on the results of diagnostic tasks, all children were divided into three groups by the level of psychomotor development.

The first group ( $0 \%$ in the ascertaining experiment, $16.7 \%$ in the control experiment) consists of preschoolers with a high level of psychomotor development. The motivational component of psychomotor activity in this group of children is characterized by a positive emotional attitude to motor activity, consistent interest in the proposed experimental tasks, and striving to continue to work. The orientational-operational is distinguished by high indicators of psychomotor development manifesting in the ability to maintain static balance and differentiate muscle tension, the ability to dynamically coordinate both general voluntary motor skills of the upper and lower extremities and fine motor skills of the hands, in precise hand-eye coordination of movements when drawing simple geometric figures and intersecting lines, in the ability to arbitrarily regulate the speed and strength of movements depending on the suggested instruction, and in sufficient differentiation of movements with complete absence of synergisms. The regulatory component of psychomotor development manifests in the children through the developed skills of self-regulation of psychomotor activity with full observance of the conditions of presented tasks. Moreover, high quality of self-control is retained by children both during the diagnostic tests and during the evaluation of results. 
The second group (the ascertaining experiment $-33.3 \%$; the control experiment $-50.0 \%$ ) includes the preschool children at the average level of psychomotor development. The motivational component of psychomotor activity in this group is characterized by the prevalence of a positive emotional attitude to motor activity, yet there is no stable interest in the offered experimental tasks, nor are the children striving to continue to work. In the orientation-operational component, a decrease in some indicators of psychomotor development appears occasionally, which manifests in the ability to hold static balance only for a limited amount of time, poor differentiation of muscle tension, the ability to dynamically coordinate the general voluntary motor skills of the upper and lower extremities with the kinesthetic and kinetic basis of fine motor skills being impaired, in imprecise hand-eye coordination of movements when drawing simple geometric figures and intersecting lines, in the ability to regulate the speed and strength of movements depending on the suggested instruction with the assumption of a single imprecision, and in satisfactory differentiation of movements with a rare manifestation of synkinesia. The regulatory component of psychomotor development is characterized in this group of children by partial acceptance of the conditions of presented tasks with a gradual decrease in the quality of self-control in the process of performing the diagnostic tests.

The third group (the ascertaining experiment $-66.7 \%$; the control experiment $-33.3 \%$ ) includes preschool children with a low level of psychomotor development. The motivational component of psychomotor activity in children in this group is characterized by the prevalence of a negative emotional attitude toward motor activity with a total lack of interest in the experimental tasks offered, as well as in continuing to work. In the orientational-operational component, a decrease in the indicators of psychomotor development is observed in the form of the inability to keep a static balance, low differentiation of muscle tension, weak dynamic coordination of general voluntary motor skills of the upper and lower extremities paired with the kinesthetic and kinetic basis of fine motor skills being impaired, compromised visual-motor coordination of movements when drawing simple geometric figures and crossing lines, the inability to regulate speed and force of the movements according to the given instructions, and in inadequate differentiation of movements with frequent synkinesias. The regulatory component of psychomotor development is characterized in this group by the children's lack of skills in the self-regulation of psychomotor activity and non-acceptance of the conditions of presented tasks, as well as by poor self-control throughout the entire performance of diagnostic tests.

The dynamics of psychomotor development of preschool children with speech pathology after the experimental training are presented in Figure 1. 
Figure 1. Distribution of preschoolers with speech pathology by levels of psychomotor development (based on the results of a control experiment).

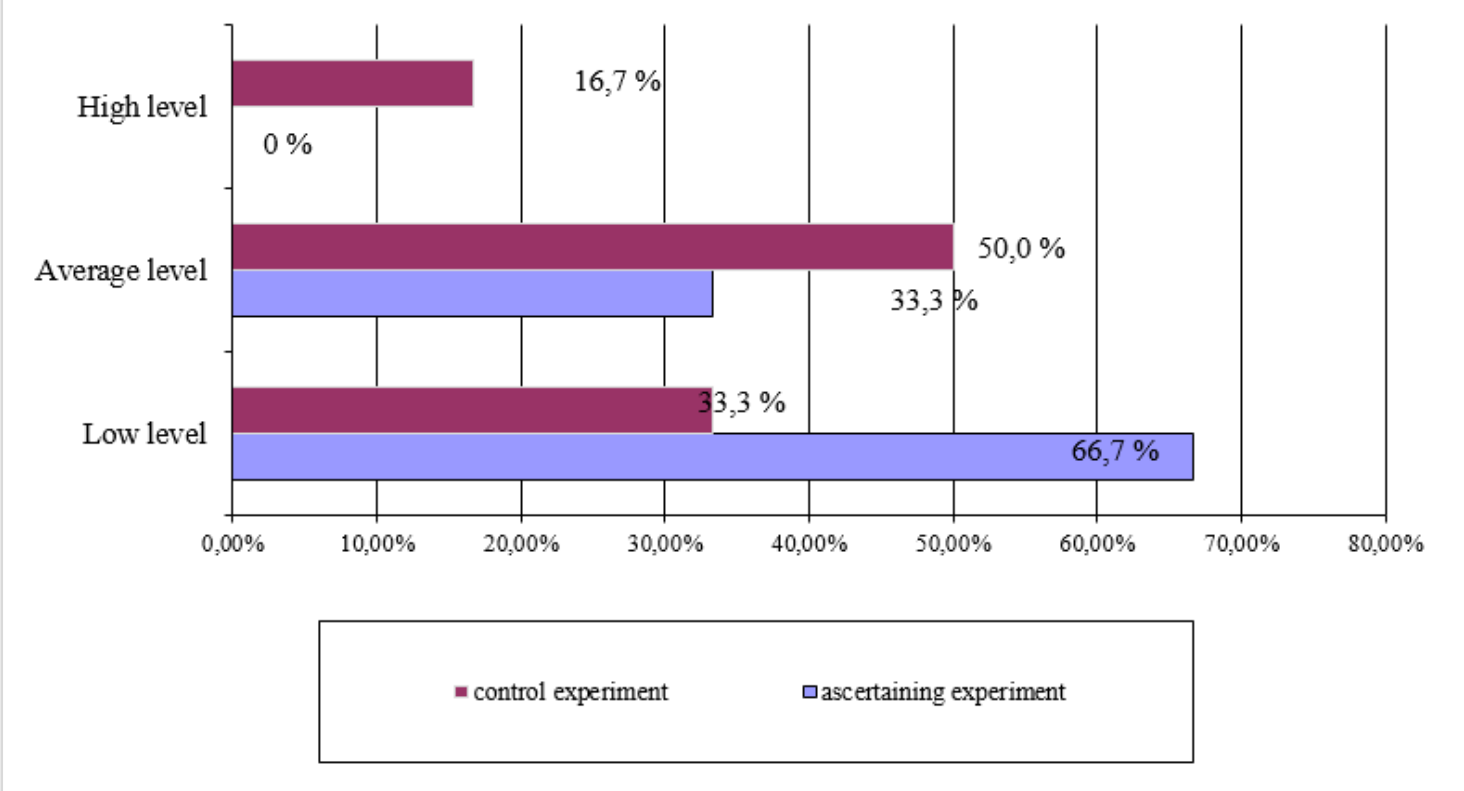

Comparing the results of the two experiments, we can conclude that the number of children at the low level has reduced by $33.4 \%$, the average level indicators have risen by $16.7 \%$, and the high level of psychomotor development not detected before the experimental learning is detected in $16.7 \%$ of the preschool children.

\section{DISCUSSION}

The present study is aimed at the search for and development of effective means of psychomotor development for preschool students with speech pathologies. Having analyzed the works of A.I. Zagrevskaya, V.S. Sosunovsky, T.N. Zalmezh (2018), S.N. Mukhina (2017), O.R. Voroshnina, and T.V. Plotnikova (2010) and correlated our results with them, we can state that the psychomotor development of this category of children manifests in the impaired accuracy and fluidity of movements, inability to hold poses, errors in spatial coordination, tension and stiffness of movements, impaired synchronization and control of movements, difficulties in performing movements according to verbal instructions, and "getting stuck" on one pose.

Our study supplements and supports the study of psychomotor development of preschool children with speech pathologies conducted by V.P. Dudev (2020). In particular, this group of students demonstrates the phenomena of motor exhaustion (slowness of pace, blurring, inaccuracy of movements), the underdevelopment of small hand movements can be observed in difficulties in performing opposite actions with each hand, in the arrhythmicity and inaccuracy of finger movements, in the imperfect processes of control and regulation of movements.

Our conclusions regarding the psychomotor development of preschoolers with speech pathologies align with the results of E.A. Kononova's study, which notes children's decreased interest in performing motor tasks, a slower pace of movement, rapid fatigue, general tension, stiffness, and insufficient coordination of arm and leg movements (Kononova, 2015).

The use of non-conventional techniques, in particular art therapy techniques, allows increasing the effectiveness of corrective work on the psychomotor development of preschool children. Arriving at conclusions similar to those of S.V. Arkhipova and M.S. Podshivalova (2020, 2021a, 2021b), we include in the experimental learning the art therapy technique of imaginative therapy, specifically, one of its types - finger puppet theatre. This technology makes it possible to 
form spatial perception and basic sensorimotor interactions in preschool children with speech pathology, enrich the sensory information they receive, transfer sensory experience into independent activity, improve their fine and gross motor skills, develop their self-control, and relieve psycho-emotional tension.

\section{CONCLUSION}

At the present stage of development of special pedagogy, the issues of psychomotor development of preschool children with speech pathologies represent a topical direction of scientific research. However, despite being popular, teaching with traditional teaching tools is insufficient. In this connection, we believe it is possible to incorporate the means of art therapy in the work on psychomotor development.

The experimental learning aimed at the development of the organizational and methodical aspects of psychomotor development of preschoolers with speech pathologies by means of art therapy technologies involves the development and testing of lessons with the use of the technology of finger puppet theater adapted to the characteristics of children in this category. The results of the control study demonstrate that the use of this technology allows improving the level of psychomotor development in children with speech pathologies.

The materials of the present article can be of use to specialists and teachers in preschool educational organizations interested in the organization of effective correctional pedagogical work in this direction.

Authors' Contributions: Arkhipova, S. V.: conception and design, acquisition of data, analysis and interpretation of data, drafting the article, critical review of important intellectual content. Lazutkina, O. R.: conception and design, acquisition of data, analysis and interpretation of data, drafting the article, critical review of important intellectual content. All authors have read and approved the final version of the manuscript.

Ethics Approval: Not applicable.

Acknowledgments: The research was carried out with the financial support of the partner university Federal State Budgetary Institution of Higher Education "I. Yakovlev Chuvash State Pedagogical University" on the topic: "Psychomotor development of children with speech pathology by means of art therapy technologies" (No. 129/2021, registration date: April 1, 2021).

\section{REFERENCES}

Arkhipova, S. V., \& Podshivalova, M. S. (2020). Osobennosti psikhomotornogo razvitiia doshkolnikov s obshchim nedorazvitiem rechi [Features of psychomotor development of preschool children with general underdevelopment of speech]. Modern Science: Actual Problems of Theory and Practice. Series: Humanitarian Sciences, 10(2), 46-49. https://doi.org/10.37882/2223-2982.2020.10-2.02

Arkhipova, S. V., \& Podshivalova, M. S. (2021a). Development of psychomotor functions in preschoolers with intellectual disabilities by means of corrective rhythmics. Propositos y Representaciones, 9(SPE2), e984. https://doi.org/10.20511/PYR2021.V9NSPE2.984

Arkhipova, S. V., \& Podshivalova, M. S. (2021b). Primenenie korrektsionno-razvivaiushchikh tekhnologii v protsesse razvitiia psikhomotornykh funktsii u doshkolnikov s ogranichennymi vozmozhnostiami zdorovia [Application of correctional and developmental technology in the development of psychomotor functions in preschool children with disabilities]. Modern Science: Actual Problems of Theory and Practice. Series: Humanitarian Sciences, 1, 41-46. https://doi.org/10.37882/2223-2982.2021.01.02

Bekhterev, V. M. (1991). Obektivnaia psikhologiia [Objective psychology]. Moscow: Nauka, 475 p.

Bezborodova, M. A. (2019). Metodiki diagnostiki psikhomotornogo razvitiia shkolnikov i doshkolnikov: Uchebnoe posobie [Diagnostic techniques for the psychomotor development of schoolchildren and preschool children: A training manual]. Moscow: MSPU, $68 \mathrm{p}$.

Davydova, G. N. (2008). Plastilinografiia dlia malyshei [Plasticine art for kids]. Moscow: Skriptorii, 48 p. 
Dudev, V. P. (2020). Psikhomotorika detei s ogranichennymi vozmozhnostiami zdorovia: Uchebnoe posobie [Psychomotor skills of children with disabilities: Textbook]. Barnaul: AltSPU, 360 p.

Gurevich, M. O., \& Ozeretskii, N. I. (1930). Psikhomotorika [Psychomotorics]. Moscow: Gosudarstvennoe meditsinskoe izdatelstvo, $72 \mathrm{p}$.

Kononova, E. A. (2015). Osnovy razvitiia psikhomotoriki u doshkolnikov [Fundamentals of psychomotor development in preschool children]. Nauka i obrazovanie: otkrytiia, perspektivy, imena, 2. Available: http://nauobraz.esrae.ru/36166

Lopatina, L. V. (2003). Izuchenie i korrektsiia narushenii psikhomotoriki u detei s minimalnymi dizartricheskimi rasstroistvami [Study and correction of psychomotor disorders in children with minimal dysarthric disorders]. Defektologiia, 5, 45-51.

Morozova, I. S., \& Garusova, O. M. (2016). Psikhomotornoe razvitie doshkolnikov: Tsikl zaniatii [Psychomotor development of preschool children: A series of classes]. Moscow: National book center, 96 p.

Mukhina, S. N. (2017). K probleme razvitiia psikhomotornoi sfery detei v sovremennom doshkolnom obrazovanii [On the problem of development of the psychomotor sphere of children in modern preschool education]. Preschool Education Today. Theory and Practice, 1, 22-26.

Nikandrov, V. V. (2004). Psikhomotorika: Uchebnoe posobie [Psychomotorics: Textbook]. Saint Petersburg: Rech, $104 \mathrm{p}$.

Pavlov, I. P. (2019). Izbrannye trudy po fiziologii vysshei nervnoi deiatelnosti [Selected works on the physiology of higher nervous activity]. Saint Petersburg: Lenaid, $256 \mathrm{p}$.

Platonov, K. K. (1986). Struktura i razvitie lichnosti: Psikhologiia lichnosti [Structure and development of personality: Psychology of personality]. Moscow: Nauka, $256 \mathrm{p}$.

Sechenov, I. M. (2019). Fiziologiia nervnoi sistemy [Physiology of the nervous system]. Moscow: lurait, 330 p.

Sirotiuk, A. L. (2009). Uprazhneniia dlia psikhomotornogo razvitiia doshkolnikov: Prakticheskoe posobie. [Exercises for psychomotor development of preschool children: A practical guide]. Moscow: Arkti, $60 \mathrm{p}$.

Susanina, I. (2007). Vvedenie v art-terapiiu: Uchebnoe posobie [Introduction to art therapy: Textbook]. Moscow: Kogito-tsentr, $95 \mathrm{p}$.

Volkova, L. S., \& Shakhovskaia, S. N. (1998). Logopediya. Uchebnik dlya studentov defektologicheskikh fakul'tetov pedagogicheskikh vysshikh uchebnykh zavedeniy [Logopedia: Textbook for students of defectology faculties of pedagogical universities]. Moscow: Vlados, $680 \mathrm{p}$.

Voroshnina, O. R., \& Plotnikova, T. V. (2010). Psikhomotornoe razvitie i fizicheskoe vospitanie detei 5-7 let s tiazhelymi narusheniiami rechi [Psychomotor development and physical upbringing of 5-7-year-old children with severe speech impairments]. Logoped, 4, 31-37.

Zagrevskaya, A. I., Sosunovsky, V. S., \& Zalmezh, T. N. (2018). Psychomotor features in preschool children. Psikhologicheskaya nauka i obrazovanie [Psychological science and education], 23(5), 13-21.

https://doi.org/10.17759/pse.2018230502

Received: 31 July 2021 | Accepted: 02 December 2021 | Published: 29 January 2022 